\section{Some engineering properties of sustainable self- compacting mortar made with ceramic and glass powders}

AвoubaKeUR BOUKHELKHAL - Research Laboratory of Civil Engineering, University of Laghouat, Algeria * a.boukhelkhal@lagh-univ.dz

AbderRamane HAMDAOUI - Research Laboratory of Civil Engineering, University of Laghouat, Algeria

BELKACEM SEBGUIG - Research Laboratory of Civil Engineering, University of Laghouat, Algeria

Érkezett: 2021. 03. 29. - Received: 29. 03. 2021. " https://doi.org/10.14382/epitoanyag-jsbcm.2022.4

\begin{abstract}
This work aims to produce a sustainable self-compacting mortar (SCM), by replacing a part of cement with powders from waste materials such as glass and ceramic. Nine mixtures have been prepared, one as reference mixture and includes only ordinary portland cement, and eight containing different proportions of ceramic and glass powders (5, 15, 25 and 50\%). In the fresh state, two tests were carried out: slump flow and flow time. In order to evaluate the physical and mechanical properties of SCM mixtures, compressive strength, flexural strength, ultrasonic pulse velocity (UPV) and water absorption were measured. The results showed that adding glass and ceramic powders until $25 \%$ improved the fresh properties of SCM. At hardened state, replacing cement by $5 \%$ of glass and ceramic powders (GP and $\mathrm{CP}$ ) resulted in acceptable physical and mechanical properties.

Keywords: self-compacting mortar, sustainable, ceramic and glass powders, fluidity, compressive strength, water absorption

Kulcsszavak: öntömörödô habarcs, fenntarthatság, kerámia- és üvegporok, folyékonyság, nyomószilárdság, vízfelvétel
\end{abstract}

\section{Introduction}

Self-compacting mortar is a highly fluid mortar that can be flow and put in place without vibration or consolidation. It is generally used to formulate self-compacting concrete (SCC) when Okamura approach is used or to repair concrete structures since it can be full all formwork spaces even in narrow gaps [1]. Cement is the most expansive component in concrete and it has a negative environmental impact due to the emission of $\mathrm{CO}_{2}$. Numerous researches were conducted around the world to produce new reduced carbon cement with low prize by using construction, industrial and agriculture wastes as fine additive materials [2-11]. Senthamarai and Manoharan [12] reported that daily production of ceramics generates about $30 \%$ of waste which their non employment poses a big environmental problem related to their deposit. Several research projects have been carried out to study the possibility of using ceramic waste as aggregates to replace natural aggregates or as filler to partially replace cement [12-14]. The use of ceramic powder (CP) in mortars and concretes results in acceptable compressive strengths with an optimal percentage of 50\%. Eldieb and Kanaan [15] have shown that the addition of $10 \%$ of CP gave a concrete with good compressive strength, while a percentage ranging between $10 \%$ and $20 \%$ improved the workability retention. From durability point of view, a percentage of $40 \%$ decreased the penetration of chloride ions and permeability, and led to increase the electrical resistivity resulting in better protection against the risk of corrosion. The incorporation of $\mathrm{CP}$ as a filler material in the composition of SCC was found to enhance flowability and passing ability. However, the hardened properties such as strength and adhesion SCC-reinforcement
Aboubakeur BOUKHELKHAL PhD, Associate professor at the Department of Civil Engineering, University of Laghouat, Algeria. His research interests include: self-compacting concrete, ordinary concrete, rheology, mechanical behavior and durability of concrete and mortar with ordinary Portland cement and mineral additions, effects of hot climate and elevated temperatures.

Abderramane HAMDAOUI MSc, Department of Civil Engineering, University of Laghouat, Algeria. His research interests include: self-compacting concrete, reuse of waste and local materials, concrete technology.

Belkacem SEBGUIG MSc, Department of Civil Engineering, University of Laghouat, Algeria. His research interests nclude: self-compacting concrete, reuse of waste and local materials, concrete technology. bars were negatively affected especially with the increase in the amount of CP [14]. High performance concretes have been successfully manufactured using $\mathrm{CP}$ with a substitution rate varying between $20 \%$ and $40 \%$ [16]. Lasseuguette et al. [17] conducted an experimental study in which two types of ceramic powder were used (white and red). They found that the white $\mathrm{CP}$ is more reactive, which was attributed to the difference observed in the chemical and mineralogical compositions.

A significant amount of glass waste is generates annually by production plants of glass elements (panels, mirrors, tubes and bottles), the workshops of glassworks and the population. This waste poses multiple problems, namely the hazardous effect related to their collection by cleaning agents, and the deterioration of the environment due to their deposit. The use of waste glass as fine additive material in cements and concretes is encouraging from multiple points of view. Rodier and Savastano [18] proved that the pozzolanic activity of glass powder (GP) increases with its grinding, and appears to have a better activity when is grinding to particles size less than $40 \mu \mathrm{m}$. Aliabdo et al. [19] have observed a linear decrease in the calcium hydroxide content with the addition of the glass powder. This is due to the reduction of the quantity of the cement is substituted by GP, and on the other hand to the pozzolanic reaction which consumes a part of C-H (Eq. (2)). Cement substitution with $10 \%$ and $20 \%$ GP improves the strength of concrete to fire and reduces the sorptivity [18]. In addition, concretes containing GP have developed superior resistance to freeze-thaw cycles compared to concrete without additions [20]. The combined use of GP and blast furnace slag was found to be very advantageous for both mechanical and transfer properties of concrete. The optimal binder composition 
that have given the best performance in terms of compression and tensile strengths, water absorption and adhesion strength (concrete-reinforcement bars) is that containing 50\% ordinary cement, $15 \% \mathrm{GP}$ and $35 \%$ blast furnace slag [21].

Hydration reaction:

$\mathrm{C}_{2} \mathrm{~S}$ or $\mathrm{C}_{3} \mathrm{~S}+\mathrm{H}_{2} \mathrm{O} \rightarrow \mathrm{C}-\mathrm{S}$-H primary $+\mathrm{Ca}(\mathrm{OH})_{2}$

Pozzolanic reaction:

$\mathrm{Ca}(\mathrm{OH})_{2}+\mathrm{SiO}_{2}$ (glass powder) $+\mathrm{H}_{2} \mathrm{O} \rightarrow \mathrm{C}$-S-H secondary

The aim of this paper is to formulate an eco-friendly selfcompacting mortar by replacing ordinary cement with fine materials from glass and ceramic wastes. Fresh and hardened properties of SCM including four different ratios of glass and ceramic powders $(5,15,25$ and $50 \%$ by mass) substituted with cement have been investigated.

\section{Materials}

According to the European Standards EN 197-1 [22], ordinary Portland cement (CEM I 42.5) was used in all mixtures. The cementitious materials used in this study are ceramic and glass powders. Ceramic powder is obtained by cleaning and grinding the residues of ceramic elements that were collected from shops (broken or industrial fault pieces) and from waste building debris materials. Glass power is obtained from broken glass which was collected from shops in Laghouat region. Table 1 shows the chemical composition and physical properties of the cement and mineral additives.

As fine aggregate, naturel river sand was used with a maximum size of $5 \mathrm{~mm}$. The physical properties of sand are given in Table 2. The chemical admixture used to produce various mixtures, is a polycarboxylates based High-Range Water Reducers (HRWR). It has a specific gravity and $\mathrm{pH}$ of $1.07 \mathrm{~g} / \mathrm{cm}^{3}$ and 8 , respectively.

\begin{tabular}{|c|c|c|c|}
\hline Component & Cement & Ceramic powder & Glass powder \\
\hline $\mathrm{SiO}_{2}(\%)$ & 18.37 & 62.3 & 70.40 \\
\hline CaO (\%) & 64.04 & 5.94 & 11.20 \\
\hline MgO (\%) & 1.52 & 0.72 & 1.60 \\
\hline $\mathrm{Al}_{2} \mathrm{O}_{3}(\%)$ & 4.26 & 16.5 & 2.54 \\
\hline $\mathrm{Fe}_{2} \mathrm{O}_{3}(\%)$ & 3.89 & 2.37 & 0.37 \\
\hline $\mathrm{SO}_{3}(\%)$ & 3.01 & 0.01 & 0.04 \\
\hline $\mathrm{K}_{2} \mathrm{O}(\%)$ & - & 0.65 & 12.25 \\
\hline $\mathrm{T}_{\mathrm{i}} \mathrm{O}_{2}(\%)$ & - & 6.78 & 0.36 \\
\hline $\mathrm{Na}_{2} \mathrm{O}(\%)$ & 0.12 & 0.31 & 0.16 \\
\hline Loss ignition (\%) & 4.23 & 3.65 & 0.82 \\
\hline Specific gravity & 3.1 & 2.6 & 2.7 \\
\hline Fineness $\left(\mathrm{cm}^{2} / \mathrm{g}\right)$ & 3921 & 3734 & 2805 \\
\hline
\end{tabular}

\begin{tabular}{lc}
\multicolumn{1}{c}{ Properties } & Sand $\mathbf{0 / 5}$ \\
\hline Absorption coefficient (\%) & 0.59 \\
\hline Density & 2.6 \\
\hline Property coefficient (\%) & 89
\end{tabular}

Table 2 Physical properties of fine aggregate 2. táblázat A használt homok fizikai tulajdonságai

\section{Mix proportion design}

Nine mortar mixtures were designed and prepared to study the effect of the ceramic and glass powders on the fresh and hardened properties of self-compacting concrete. Ceramic and glass powders were included by replacing a part of cement at substitution levels of 5, 15, 25 and 50\%. In all SCM mixtures, the amount of binder, $\mathrm{W} / \mathrm{B}$ ratio and dosage of SP were kept equal to $690.65 \mathrm{~kg}, 0.4$ and $1.1 \%$, respectively. The mix proportions of all SCM are given in Table 3.

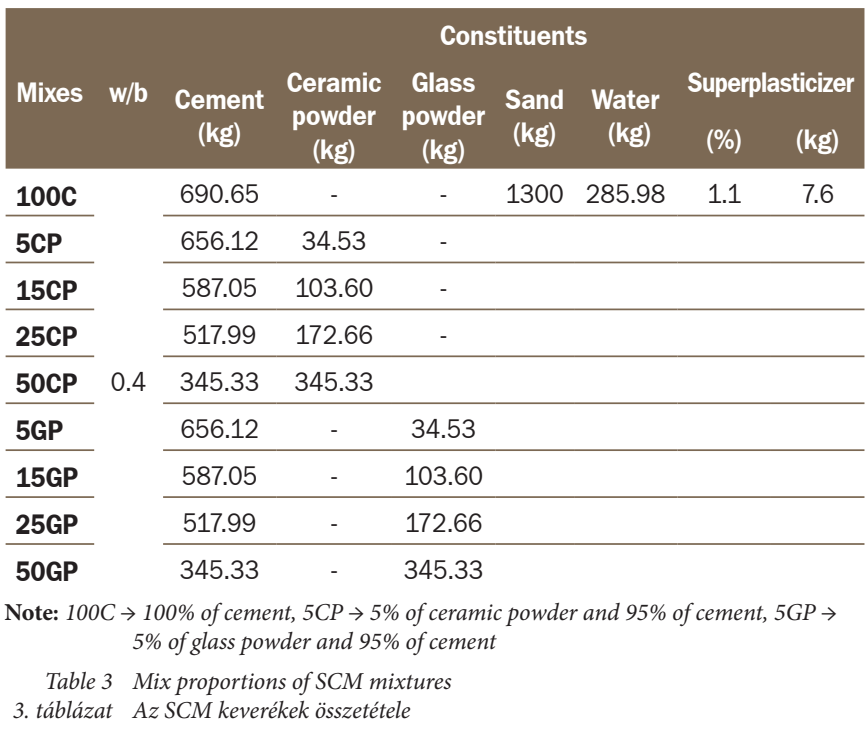

\section{Test procedure}

\subsection{Fresh mortar}

The mini slump flow and mini v-funnel tests were conducted to characterize the flowability, filling ability and stability of fresh mortar. In the mini slump flow (Fig. 1.a), a truncated cone mold was filled with mortar and lifted upwards. The final diameter of the mortar through two perpendicular directions was measured and the mean is calculated. Slump flow ranging between 27.5 and $33.5 \mathrm{~cm}$ are suggested to obtain a slump flow of $55-85 \mathrm{~cm}$ for SCC [23-24].

It can be noted that it is possible to evaluate the trend to segregation or bleeding of SCM through visual control. The mini v-funnel was filled completely with mortar and the bottom outlet is opened allowing to the mortar to flow out (Fig. 1.b). The v-funnel flow time Tv which is the elapsed time (s) between the opening of the bottom outlet and the time when the light becomes visible from the top was measured [25].

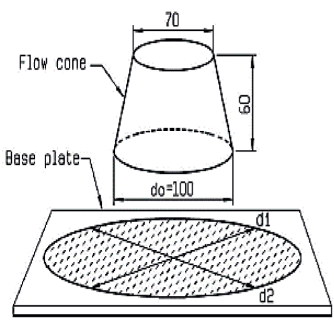

(a)

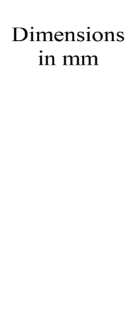

(b)
Fig. 1 Self-compacting mortar tests, (a) schematization of the mini-slump flow test, (b) mini V-funnel test

1. ábra Öntömörödő habarcsvizsgálatok sematikus ábrái: (a), mini roskadásvizsgálat (b) mini V-tölcséres vizsgálat 


\subsection{Hardened mortar}

From each mortar mixture, prismatic specimens of $40 \times 40 \times 160 \mathrm{~mm}$ in size were cast. After casting, all specimens were covered with plastic sheets for 24 hours, before they unmolded and transferred to conservation in water saturated with lime at $20 \pm 2{ }^{\circ} \mathrm{C}$ and $95 \%$ relative humidity until the aging test. For each mix, three specimens were used to determine flexural strength, ultrasonic pulse velocity, water absorption, and six specimens to measure compressive strength at 3, 28 and 90 days. All these measures were carried out following European Standard EN 196-1 and EN 12504-4 [26-27].

\section{Results and discussion}

\subsection{Fresh mortar}

\subsubsection{Slump flow}

The evolution of slump flow as function of mineral addition percentages is presented in Fig. 2. The results indicated an increase in slump flow when a part of cement is replaced by glass and ceramic powders. The heights values of slump diameter were noted in mixtures containing 5 and $50 \%$ of CP and 50\% of GP. All mixtures satisfied flowability requirements in term of slump flow values $(27.5-33.5 \mathrm{~cm})$ [23-24]. Subaci et al. [14] were observed an improvement on the flowability properties of self-compacting concrete with waste ceramic powder until substitution level of $15 \%$. Through visual control, it was noted some bleeding in mixtures having $50 \%$ of GP and CP. From these results, it can be concluded that flowability and homogeneity of SCM in which cement was partially replaced by different proportions of ceramic and glass powders were relatively higher compared to reference SCM mixture, with exception for mixtures containing a large proportion of glass and ceramic powders (50\%).

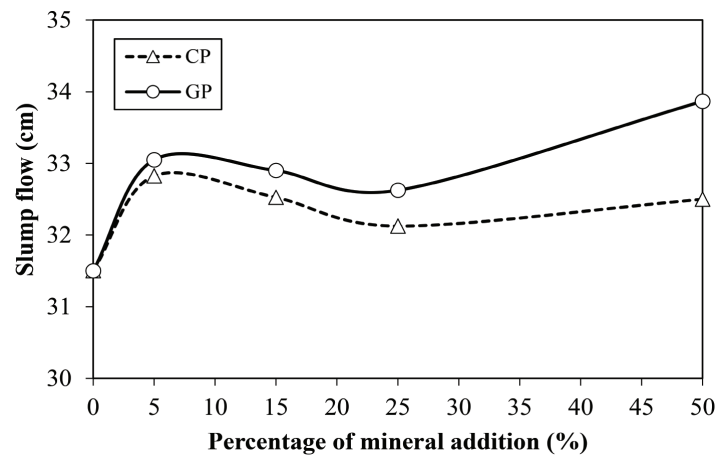

Fig. 2 Slump flow for mortar mixtures with plain and blended cements

2. ábra Sima és kevert cementes habarcskeverékek roskadásvizsgálatának eredményei

\subsubsection{Flow time}

The values of flow time are plotted against the percentage of mineral additions in Fig. 3. The results showed that the flow time values of all mixtures were between 2.71 and $3.90 \mathrm{~s}$, these values are acceptable since they are in the range proposed by EFNARC (2 to $10 \mathrm{~s}$ ) [25]. It was noted that all mixtures had lower flow time values than the reference mixture. The obtained results from Figs. 2 and 3 indicated that partial replacement of cement with both ceramic and glass powders with a percentage lower than $25 \%$ was found to be very positive in improving the fluidity and homogeneity of self-compacting mortar.
These results may be explained by improving the cohesion at the interface paste-fine aggregate in reason of the replacement of cement with a fine materials that having different size and shape. Another reason can explain these results which is the lower density of ceramic and glass powders compared to the cement which increases the paste volume, reduces the contacts between fine aggregate, and improves therefore the fluidity and facilities the movement of SCM [28]. It can be concluded that it is possible to reduce the amount of superplasticizer in order to produce homogeneous and economical SCM with similar fluidity to the control mixture by using waste local materials such as glass and ceramic as powders.

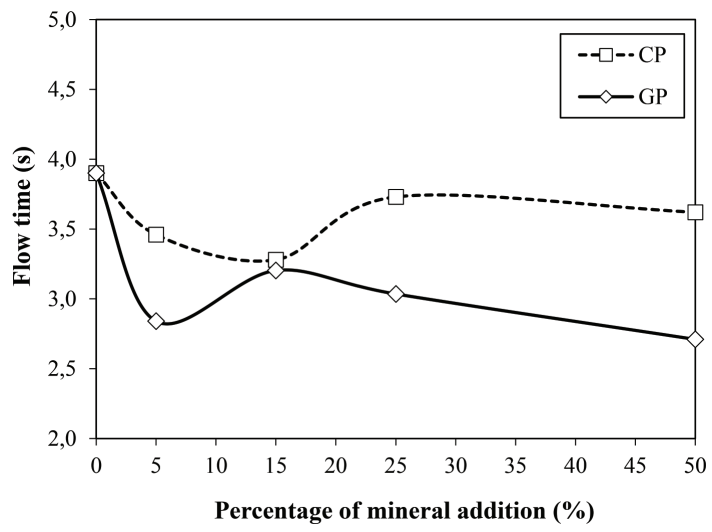

Fig. 3 Flow time for mortar mixtures with plain and blended cements 3. ábra Folyási idő sima és kevert cementekkel készült habarcskeverékeknél

\subsection{Hardened mortar}

\subsubsection{Compressive strength}

The effect of ceramic and glass powders on compressive strength at 3, 28 and 56 days can be observed in Figs 4, 5 and 6, respectively. As it can be seen in Fig. 4, mixtures made with $5 \%$ of GP and CP were developed compressive strength higher (35.79 and $33.43 \mathrm{MPa}$, respectively) than that of reference mix (33.20 MPa). On the other hand, the results showed that the mixtures including $50 \%$ of ceramic and glass powders have the lowest compressive strength with $14.84 \mathrm{MPa}$ and $12.84 \mathrm{MPa}$, respectively, these values are 61 and 55\% lower compared to mixture with plain cement. It was noted that increasing powders content led to lower compressive strength. In addition, mixtures containing GP have developed superior compressive strength compared to mixtures with corresponding CP content. The same results were observed at 28 days (Fig. 5). The decrease in compressive strength for mixtures including 5, 15, 25 and $50 \%$ of ceramic powder was $4,15,34$ and $57 \%$, respectively. In the case of glass powder, the compressive strength was reduced by $5,24,34$ and $48 \%$ for mixtures with GP content of 5,15 , 25 and 50\%, respectively. Fig. 6 showed an improvement in compressive for mixtures made with GP. Adding 5 and 15\% of GP resulted in similar compressive strength to control mix, whereas percentage of $25 \%$ led to compressive strength superior by $3 \%$ to that of mixture without additions. In their research, Aliabdo et al. [19] were noted an enhancement in compressive strength, tensile strength, absorption voids ratio and density as a result of using $10 \%$ glass powder cement replacement. 


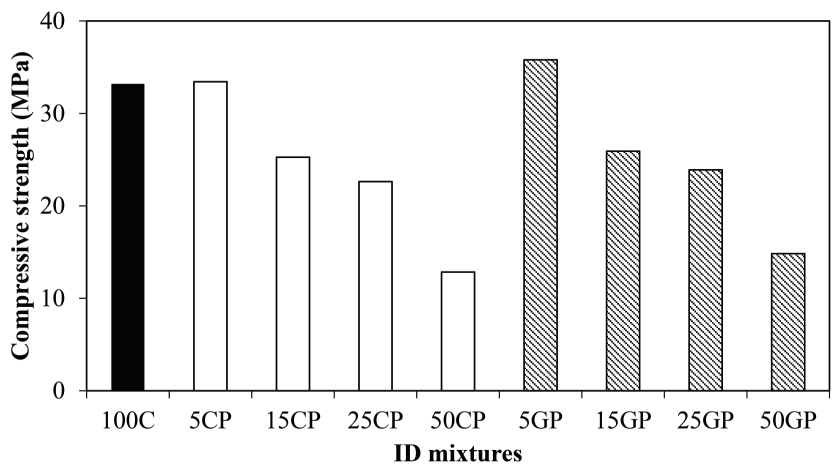

Fig. 4 Compressive strength for mortar mixtures with plain and blended cements at 3 days

4. ábra Nyomószilárdság habarcskeverékekhez sima és kevert cementekkel 3 napos korban

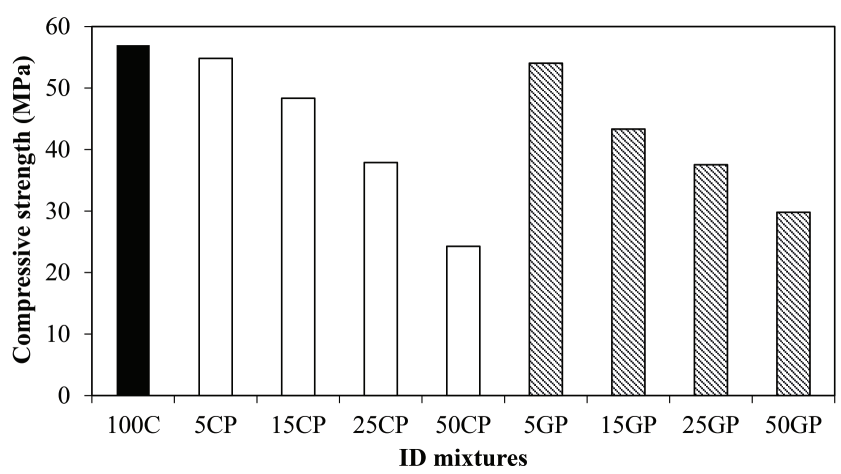

Fig. 5 Compressive strength for mortar mixtures with plain and blended cements at 28 days

5. ábra Nyomószilárdság habarcskeverékekhez sima és kevert cementekkel 28 napos korban

The increase of the compressive strength of mixtures including GP and $\mathrm{CP}$ at 56 days demonstrated the positive affect of partial replacement of cement with fine pozzolanic powders. This participate to filling the voids and pores which increases the density. The pozzolanic reaction between $\mathrm{SiO}_{2}$ (from powders) and calcium hydroxide, which lead to the formation of new hydrated compounds (hydrated calcium silicate), this fills the micro spaces and results in higher compaction and strength.

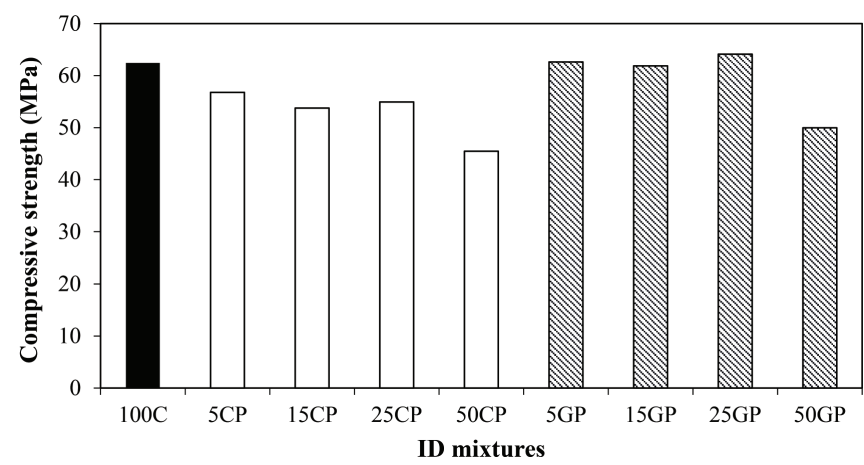

Fig. 6 Compressive strength for mortar mixtures with plain and blended cements at 56 days

6. ábra Nyomószilárdság habarcskeverékekhez sima és kevert cementekkel 56 napos korban

Torkittikul and Chaipanich [29] were studied the effect of ceramic waste as fine aggregate on some engineering properties of concretes. They reported an increase in the compressive strength by increasing the substitution level $(0,10,20,30,40$ et $50 \%$ ) of natural sand by ceramic waste.

\subsubsection{Flexural strength}

Fig. 7 depicts the variation of flexural strength for different compositions. The results of Fig. 7 indicated that the use of ceramic and glass powders at 5 and $15 \%$ resulted in flexural strength superior by 4 and $19 \%$ to that of plain cement mixture, while increasing the percentage of cement substituted by ceramic and glass powders to more than $15 \%$ led to a significant decrease in the flexural strength. This decrease achieved higher values in the mixtures made with $50 \%$ of glass and ceramic powders.

The effect of GP and CP replacement as fine powders at 5 , 15,25 and $50 \%$ on the flexural strength of SCM at 28 days is shown in Fig. 8. By analyzing the results of flexural strength after 28 days, it can note an improvement in flexural strength for mixture with $5 \%$ of glass powder, which reached flexural strength value of 7.44 MPa, whereas control mix had a flexural strength of $7.38 \mathrm{MPa}$. The addition of glass and ceramic powders by 15 and $25 \%$ led to lower flexural strength compared to the plain cement mixture. Increasing the percentage of fine additions resulted in poor flexural strength.

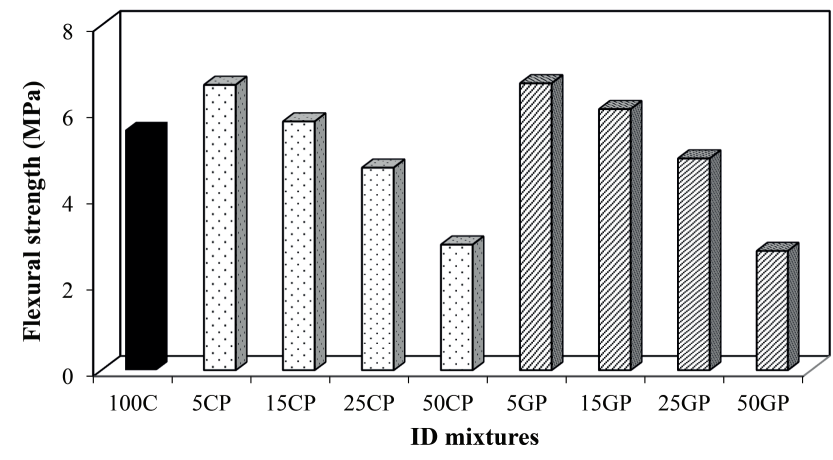

Fig. 7 Flexural strength for mortar mixtures with plain and blended cements at 3 days

7. ábra Hajlitószilárdság habarcskeverékekhez sima és kevert cementekkel 3 napos korban

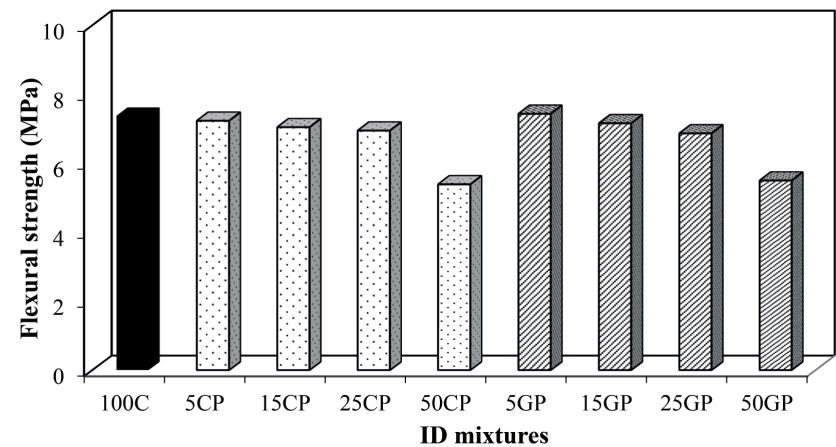

Fig. 8 Flexural strength for mortar mixtures with plain and blended cements at 28 days

8. ábra Hajlitószilárdság habarcskeverékekhez sima és kevert cementekkel 28 napos korban

Fig. 9 illustrates the evolution of flexural strength at 56 days for all tested SCM mixtures. It can be remarked an increase in flexural strength in mixtures containing GP especially those 
made with 5 and $25 \%$ of GP. Replacing cement by GP gave higher flexural strength compared to mixtures with corresponding content of CP. The higher values of flexural strength, especially in mixtures containing 5, 15 and $25 \%$ of ceramic and glass powders, are attributed to the irregular particles shape of these powders, this increases the cohesion between the particles of paste and contributes to better flexural strength.

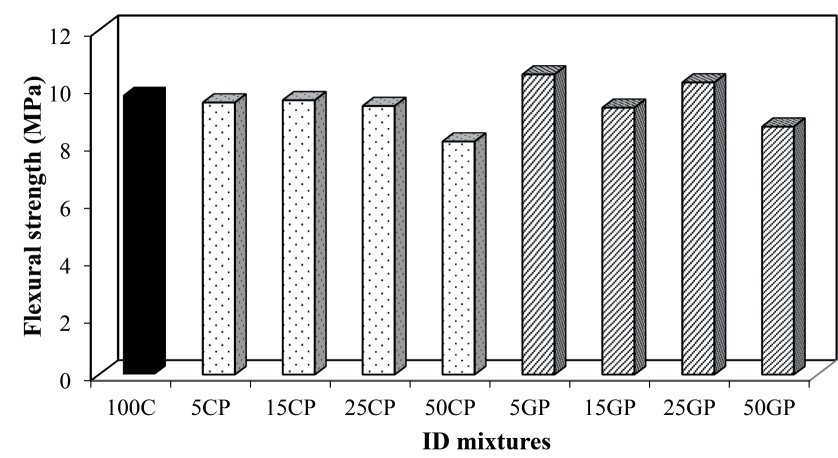

Fig. 9 Flexural strength for mortar mixtures with plain and blended cements at 56 days 9. ábra Hajlitószilárdság habarcskeverékekhez sima és kevert cementekkel 56 napos korban

\subsubsection{Ultrasonic Pulse Velocity}

Fig. 10 presents the variation of ultrasonic pulse velocity at 28 and 56 days. It was observed a decrease in UPV at 28 days with the addition of ceramic and glass powder. At 56 days, UPV increased for all mixtures by 1 to $5 \%$. Adding $5 \%$ of glass powder appeared to be the optimal percentage as it gave similar UPV to control mix.

The increase in UPV between 28 and 56 days is mainly due to the continuation of cement hydration which led to the formation of hydrated components. Glass and ceramic powders are considered as a pozzolanic materials, so they contribute to increase the density of SCM, by filling the voids and pores and by the formation of additionally hydrated calcium silicate (C-S-H), which in turn plays in important role in filling spaces and micro spaces.

Whitehurst [30] was classified the concretes according to their quality as following: excellent, good, moderate, bad and very bad for an UPV values above $4.5 \mathrm{~km} / \mathrm{s}, 3.5-4.5 \mathrm{~km} / \mathrm{s}$, $3.0-3.5 \mathrm{~km} / \mathrm{s}, 2.0-3.0 \mathrm{~km} / \mathrm{s}$ and lower or equal to $2.0 \mathrm{~km} / \mathrm{s}$, respectively. This classification indicated that all the mixtures tested at 28 and 56 days have a good quality.

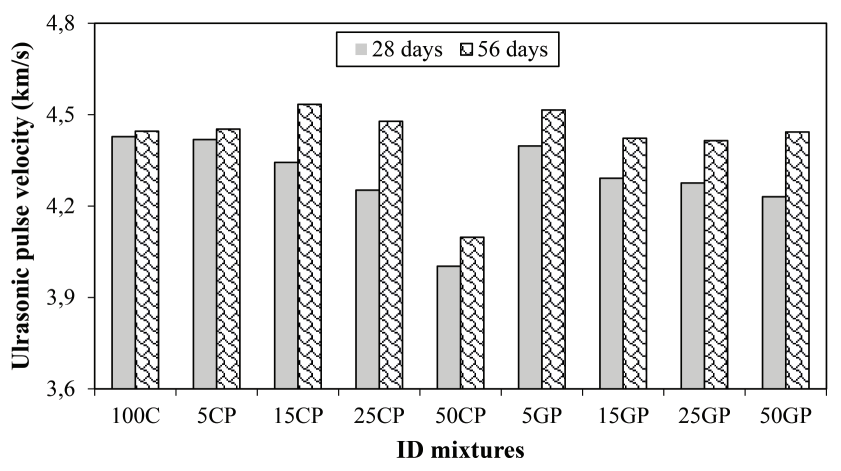

Fig. 10 Ultrasonic pulse velocity for mortar mixtures with plain and blended cements at 28 and 56 days

10. ábra Ultrahangos impulzussebesség értékei sima és kevert cementet tartalmazó habarcskeverékeknél 28 és 56 napos korban

\subsubsection{Water absorption}

Fig. 11 shows the evolution of water absorption for all tested mixtures. It can be observed an increase in water absorption with adding glass and ceramic powders. Water absorption values of mixtures with blended cement are higher than mixture with plain cement, except for mixture made with 5\% of GP which has the lowest value of water absorption. The replacement of cement with CP resulted in higher water absorption compared to mixtures including GP. It can conclude that the use of GP with $5 \%$ is optimal to reduce water absorption of SCM mixtures. According to Rodier and Savastano [18], the partial subsitution of cement by $10 \%$ of glass powder residue leads to a decrease in water absorption by about $15 \%$ in comparison to mortar without mineral addition.

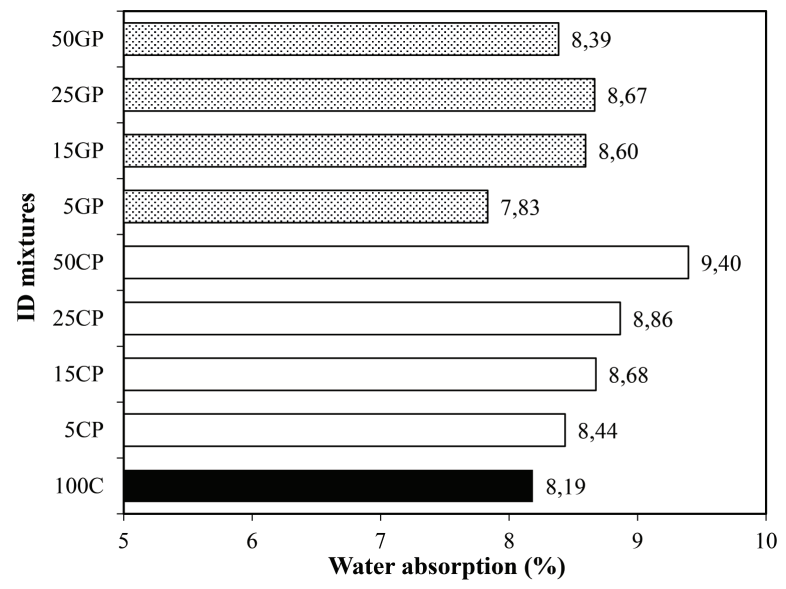

Fig. 11 Water absorption for mortar mixtures with plain and blended cements 11. ábra Vizfelvétel sima és kevert cementes habarcskeverékekhez

\section{Conclusions}

Based on the experimental results and the analysis performed, the following conclusions can be drawn:

- The use of ceramic and glass powders by up to $25 \%$ contributes to the production of homogeneous selfcompacting with acceptable fluidity and viscosity, while percentage of $50 \%$ led to heterogeneous mixtures with clear bleeding signs.

- Adding CP and GP makes possible to reduce the dosage of superplasticizer in order to produce an economical and homogeneous self-compacting mortar with similar flowability to control mix.

- The partial replacement of cement by $5 \%$ of ceramic and glass powders gave compressive and flexural strengths equal or greater than that of the plain cement mix, while exceeding this percentage, especially at 50\%, had a negative effect on mechanical properties.

- Increasing ultrasonic pulse velocity led to compact mortar with longer life. Generally, UPV decreased with the increase in the percentage of glass and ceramic powders.

- The use of $5 \%$ glass powder is ideal for reducing water absorption. 


\section{Acknowledgments}

The authors express their gratitude to the Directorate General for Scientific Research and Technological Development (DGRSDT-Algeria) for assistance and funding the experimental work.

\section{References}

[1] Benabed, B., Soualhi, H., Belaidi, A.S.E., Azzouz, L., Kadri, E.H., Kenai S. Effect of limestone powder as a partial replacement of crushed quarry sand on properties of self-compacting repair mortars. Journal of Building Materials and Structures, 2016. 3. Pp. 15-30. https://doi.org/10.5281/ZENODO.242480

[2] Saluja, S., Goyal, S., Bhattacharjee, B. Strength and abrasion resistance of roller compacted concrete incorporating GGBS and two types of coarse aggregates. Advances in Concrete Construction, 2019. 8. Pp. 127-137. https://doi.org/10.12989/acc.2019.8.2.127

[3] Boukhelkhal, A., Benabed, B. Fresh and hardened properties of selfcompacting repair mortar made with a new reduced carbon blended cement. Journal of Silicate Based and Composite Materials, 2019. 71. Pp. 108-113. https://doi.org/10.14382/epitoanyag-jsbcm.2019.19

[4] Baghabra Al Amoudi, O.S., Shamsad, A., Khan, S.M.S., M. Maslehuddin. Durability performance of concrete containing Saudi natural pozzolans as supplementary cementitious material. Advances in Concrete Construction, 2019. 8. Pp. 119-126. https://doi.org/10.12989/acc.2019.8.2.119

[5] Boukhelkhal, A., Azzouz, L., Kenai, S., Kadri, E.H., Benabed, B. Combined effects of mineral additions and curing conditions on strength and durability of self-compacting mortars exposed to aggressive solutions in the natural hot-dry climate in North African desert region. Construction and Building Materials, 2019. 197. Pp. 307-318.

https://doi.org/10.1016/j.conbuildmat.2018.11.233

[6] Ouldkhaou, Y., Benabed, B., Abousnina, R., Kadri, E.H. Experimental study on the reuse of cathode ray tubes funnel glass as fine aggregate for developing an ecological self-compacting mortar incorporating metakaolin, Journal of Building Engineering, 2020. 20. Pp. 1-11. https://doi.org/10.1016/j.jobe.2019.100951

[7] Boukhelkhal, A., Azzouz, L., Benabed, B., Belaïdi, A.S.E. Strength and durability of low-impact environmental self-compacting concrete incorporating waste marble powder, Journal of Building Materials and Structures, 2017. 4. Pp. 31-41. https://doi.org/10.5281/zenodo.1134146

[8] Laidani, Z.E.A., Benabed, B., Abousnina, R., Gueddouda, M.K., Kadri, E.H. Experimental investigation on effects of calcined bentonite on fresh, strength and durability properties of sustainable self-compacting concrete. Construction and Building Materials, 2020. 230. Pp. 1-11. https://doi.org/10.1016/j.conbuildmat.2019.117062

[9] Alipour, P., Namnevis, M., Tahmouresi, B., Mohseni, E., Tang, W. Assessment of flowing ability of self-compacting mortars containing recycled glass powder. Advances in Concrete Construction 2019. 8. Pp. 6576. DOI: https://doi.org/10.12989/acc.2019.8.1.065

[10] Sasanipour, H., Aslani, F., Taherinezhad, J. Effect of silica fume on durability of self-compacting concrete made with waste recycled concrete aggregates. Construction and Building Materials, 2019. 227. Pp. 1-12. https://doi.org/10.1016/j.conbuildmat.2019.07.324

[11] Gritsada, S., Natt, M., Shanshan, C., Prakasit, S. Workability and compressive strength development of self-consolidating concrete incorporating rice husk ash and foundry sand waste - A preliminary experimental study. Construction and Building Materials, 2019. 228. Pp. 1-7. https://doi.org/10.1016/j.conbuildmat.2019.116813

[12] Senthamarai, R.M., Manoharan, P.D. Concrete with ceramic waste aggregate. Cement and Concrete Composites, 2005. 27. Pp. 910-913. https://doi.org/10.1016/j.cemconcomp.2005.04.003

[13] Gonzalez-Corominas, A., Etxeberria, M. Properties of high performance concrete made with recycled fine ceramic and coarse mixed aggregates. Construction and Building Materials, 2014. 68. Pp. 618-626. https://doi.org/10.1016/j.conbuildmat.2014.07.016

[14] Subaşı, S., Öztürk, H., Emiroğlu, M. Utilizing of waste ceramic powders as filler material in selfconsolidating concrete, Construction and Building
Materials, 2017. 149. Pp. 567-574.

https://doi.org/10.1016/j.conbuildmat.2017.05.180

[15] El-Dieb, A.S., Kanaan, D.M. Ceramic waste powder an alternative cement replacement-Characterization and evaluation. Sustainable Materials Technologies, 2018. 17. Pp. 1-11.

https://doi.org/10.1016/j.susmat.2018.e00063

[16] Kannan, D.M., Aboubakr, A.H., EL-Dieb, A.S., Taha, M.M.R. High performance concrete incorporating ceramic waste powder as large partial replacement of Portland cement, Construction and Building Materials, 2017. 144. Pp. 35-41. https://doi.org/10.1016/j.conbuildmat.2017.03.115

[17] Lasseuguette, E., Burns, S., Simmons, D., Francis, E., Huang, Y. Chemical, microstructural and mechanical properties of ceramic waste blended cementitious systems. Cleaner Production, 2019. 211. Pp. 1228-1238. https://doi.org/10.1016/j.jclepro.2018.11.240

[18] Rodier, L., Savastano, H. Use of glass powder residue for the elaboration of eco-efficient cementitious materials. Cleaner Production, 2018. 184. Pp. 333-341. https://doi.org/10.1016/j.jclepro.2018.02.269

[19] Aliabdo, A., Abd Elmoaty, M.M., Aboshama, A.Y. Utilization of waste glass powder in the production of cement and concrete. Construction and Building Materials, 2016. 124. Pp. 866-877. https://doi.org/10.1016/j.conbuildmat.2016.08.016

[20] Lee, H., Hanif, A., Usman, M., Sim, J., Oh, H. Performance evaluation of concrete incorporating glass powder and glass sludge wastes as supplementary cementing material. Cleaner Production, 2018. 170. Pp. 683-693. https://doi.org/10.1016/j.jclepro.2017.09.133

[21] Ramakrishnan, K., Pugazhmani, G., Sripragadeesh, R., Muthu, D., Venkatasubramanian, C. Experimental study on the mechanical and durability properties of concrete with waste glass powder and ground granulated blast furnace slag as supplementary cementitious materials. Construction and Building Materials, 2017. 156. Pp. 739-749. https://doi.org/10.1016/j.conbuildmat.2017.08.183

[22] EN 197-1. Methods of testing cement-Part 1: Composition, specifications and conformity criteria for common cements. 2011.

[23] Skarendahl, A. The present-The future. Proceedings of III International RILEM Symposium on Self-Compacting Concrete. Bagneux, France, 2003. Pp. 6-14.

[24] Domone, P.L. Self-compacting concrete: An analysis of 11 years of case studies. Cement and Concrete Composite, 2006. 28. Pp. 197-208. https://doi.org/10.1016/j.cemconcomp.2005.10.003

[25] EFNARC. Specification and Guidelines for Selfcompacting Concrete. European Federation of Producers and Applicatorsof Specialist Products for Structures, EFNARC, Norfolk, 2002. 32 p.

[26] EN 196-1. Methods of testing cement-Part 1: Determination of strength. 2002.

[27] EN 12504-4. Essais pour béton dans les structures - Partie 4: détermination de la vitesse de propagation du son. 2005.

[28] Boukhelkhal, A., Azzouz, L., Belaïdi, A.S.E., Benabed, B. Effects of marble powder as a partial replacement of cement on some engineering properties of self-compacting concrete. Journal of Adhesion Science and Technologie, 2016. 30. Pp. 2405-2419. https://doi.org/10.1080/01694243.2016.1184402

[29] Torkittikul, P., Chaipanich, A. Utilization of ceramic waste as fine aggregate within Portland cement and fly ash concretes. Cement and Concrete Composite, 2010. 32. Pp. 440-449.

https://doi.org/10.1016/j.cemconcomp.2010.02.004

[30] Whitehurst, E.A. Soniscope tests concrete structures. Journal of American Concrete Institute, 1951. 47. Pp. 443-444.

Ref.:

Boukhelkhal, Aboubakeur - Abderramane, Hamdaoui - Belkacem, Sebguig: Some engineering properties of sustainable self-compacting mortar made with ceramic and glass powders

Építöanyag - Journal of Silicate Based and Composite Materials, Vol. 74, No. 1 (2022), 21-26. p.

https://doi.org/10.14382/epitoanyag-jsbcm.2022.4 